\title{
Cascading effect of three-spined stickleback Gasterosteus aculeatus on community composition, size, biomass and diversity of phytoplankton in shallow, eutrophic brackish lagoons
}

\author{
Tue Stenholm Jakobsen ${ }^{1}$, Pia Borch Hansen ${ }^{1,2}$, Erik Jeppesen ${ }^{1,2, *}$, Martin Søndergaard ${ }^{1}$ \\ ${ }^{1}$ Department of Freshwater Ecology, National Environmental Research Institute, Vejlsøvej 25, PO Box 314, \\ 8600 Silkeborg, Denmark \\ ${ }^{2}$ Department of Plant Biology, Biological Institute, Aarhus University, Nordlandsvej 68, 8240 Risskov, Denmark
}

\begin{abstract}
We conducted a 4 mo mesocosm experiment to elucidate the cascading impact of the zooplanktivorous three-spined stickleback Gasterosteus aculeatus on phytoplankton in slightly brackish lakes. The mesocosms were nutrient-enriched with low salinity ( $2 \mathrm{psu}$ ) and contrasting densities of sticklebacks ( 0 to 10 fish $\mathrm{m}^{-2}$ ). Total phytoplankton biovolume increased by 2 orders of magnitude when stickleback density increased from 0 to 3 to 6 to 10 fish $\mathrm{m}^{-2}$, most likely reflecting a parallel change in zooplankton biomass and size distribution. Phytoplankton size distribution was affected in that large forms dominated at high fish density, which most likely reflects a parallel reduction in size of zooplankton. A few taxa (especially Cryptophyceae) dominated at fish densities above 3 to 6 fish $\mathrm{m}^{-2}$, whereas higher diversity (characterised by taxa of Bacillariophyceae and Chlorophyceae) was recorded at fish densities below 3 to $6 \mathrm{~m}^{-2}$. However, genera richness showed no significant relationship with fish density. The threshold fish density for a transition from low to high phytoplankton biovolume at these high nutrient levels was 3 to 6 fish $\mathrm{m}^{-2}$. This level lies well below stickleback densities found in many eutrophic, low-salinity lagoons, implying that the intensity of the cascading top-down effect exerted by planktivorous fish on the phytoplankton abundance and community structure is of importance.
\end{abstract}

KEY WORDS: Sticklebacks $\cdot$ Phytoplankton diversity $\cdot$ Top-down control $\cdot$ Trophic cascade $\cdot$ Saline $\cdot$ Brackish lakes Resale or republication not permitted without written consent of the publisher

\section{INTRODUCTION}

The cascading trophic interactions hypothesis suggests that nutrient supply determines the potential productivity of an aquatic ecosystem, whereas the deviation of the actual from the potential productivity is caused by variability in predator-prey interactions and their influence on community structure (Carpenter et al. 1987). According to this hypothesis, alterations at the top of the food web cascade to the lower trophic levels, the major process involved being the concept of selective predation by consumers on prey type and size, which shapes the structure of each lower trophic level (top-down control) as demonstrated in many freshwater lakes (Kitchell \& Carpenter 1993).

Trophic structure and dynamics of eutrophic brackish lakes differ substantially, however, from eutrophic freshwater lakes (Jeppesen et al. 1994). They are typically species-poor and generally lack large-sized mussels (Moss 1994), and the zooplankton:phytoplankton 
ratio is markedly lower, indicating lower grazing pressure on phytoplankton. Yet, how phytoplankton responds to changes in fish densities has received little attention. The salinity of most Danish brackish lakes is low ( 0.5 to $8 \mathrm{psu}$ ) and the lakes are characterised by low water depth, high nutrient levels, a low zooplankton:phytoplankton biomass ratio and low water transparency (Jeppesen et al. 1997a, Jensen et al. 2000). Planktivorous fish, mainly sticklebacks, constitute the major part of the fish community and apparently maintain a high predation pressure on zooplankton (Jeppesen et al. 1997b). To further elucidate the structuring role of planktivorous fish in eutrophic-hypereutrophic, shallow, brackish lakes, a mesocosm experiment adjusted to low salinity ( $2 \mathrm{psu}$ ) and a high nutrient level was conducted at contrasting densities of three-spined sticklebacks. In an earlier paper (Jakobsen et al. 2003) we reported the effects on the zooplankton community; here, we describe changes in phytoplankton biovolume, composition and size.

\section{MATERIALS AND METHODS}

Experimental set-up and design. The experiments were carried out from 3 May to 20 September 2000 in the slightly brackish (0.5 psu) Lake Kogleaks, located in the northern part of the nature reserve Vejlerne, Denmark. Eleven cylindrical, polyethylene enclosures (surface area $\approx 1 \mathrm{~m}^{2}$ ) were fixed in and kept open to the sediment at a water depth between 70 and $80 \mathrm{~cm}$ (Jakobsen et al. 2003).

Each enclosure was stocked with three-spined sticklebacks (average weight $1.7 \mathrm{~g} \pm 0.3$, average length $5.8 \mathrm{~cm} \pm 0.4)$ in 6 different densities $\left(0,1,2,4,8,16 \mathrm{~m}^{-2}\right)$.

Upon establishment, the salinity of the enclosures was adjusted to 2 psu by adding a solution of $\mathrm{NaCl}$, $\mathrm{MgSO}_{4}$ and $\mathrm{NaHCO}_{3}$. The enclosures were then inoculated with additional sediments $(200 \mathrm{ml})$ and water samples (100 or $200 \mathrm{ml}$ from each location) from brackish and marine waters covering a salinity gradient from 1 to $22 \mathrm{psu}$. Total nitrogen and total phosphorus concentrations were adjusted to a high level of 3.5 and $0.4 \mathrm{mg} \mathrm{l}^{-1}$, respectively, to avoid nutrient limitation in the experiment (Jakobsen et al. 2003). Throughout the sampling period salinity was adjusted and nutrients, equivalent to the initial solutions, were added monthly to the enclosures. The enclosures were kept free of macrophytes (mainly Myriophyllum spicatum L. and Lemna minor L.) by harvesting.

Sampling methods and processing of samples. Samplings were conducted weekly from 16 May to 14 June and then bi-weekly until 20 September. Samples for chemical analyses and phytoplankton were collected with a tube sampler (length $=1.85 \mathrm{~m}$, depth $=7 \mathrm{~cm}$ ).
For analysis of chemical and physical variables, see Jakobsen et al. (2003). For identification of phytoplankton, a $50 \mathrm{ml}$ sample was preserved with $1 \mathrm{ml}$ Lugol's solution immediately after sampling.

Phytoplankton was enumerated for 6 samplings between 7 June and 20 September. The counting was carried out using an inverted microscope at 400× magnification. Depending on the sample concentration, 5, 10 or $20 \mathrm{ml}$ sedimentation chambers were used and the samples were diluted if necessary. Algae identification was conducted to genera or, if possible, to species level. Cell volumes were calculated from linear measurements using the appropriate geometric formulae (Olrik 1991). Genera/species biovolume $\left(\mathrm{mm}^{3} \mathrm{ww} \mathrm{l} \mathrm{l}^{-1}\right.$ ) was calculated by multiplying average cell volume by cell population density. Average greatest axial linear dimension (GALD) was recorded, omitting the large colonies of Cyanophyceae because of inaccuracy in measurement. Phytoplankton diversity or abundance was estimated as Shannon diversity $\left(H^{\prime}=-\Sigma \mathrm{p}_{\mathrm{i}} \log _{2} \mathrm{p}_{\mathrm{i}}\right.$, where $\mathrm{p}_{\mathrm{i}}$ is the relative contribution to the biovolume of genera. Phytoplankton richness was recorded as number of genera present during the experimental period. Fish density was recorded 4 times throughout the experimental period, and adjusted if fish kill had occurred. Based on these recordings a time-weighted average of stickleback density was calculated for each enclosure $(0,0,1,1,1.3,1.6,2.9,6.9,7.6,9.4,10.2)$ (Jakobsen et al. 2003).

Statistical analyses. The effects of fish and zooplankton on phytoplankton size and biovolume were assessed by regression analyses. Time-weighed averages of phytoplankton, zooplankton and fish data for each mesocosm were used. Dependent variables were $\log _{\mathrm{e}}$-transformed to stabilise variance. As data from some dependent variables fall in 2 blocks (low: 0 to 3 fish $\mathrm{m}^{-2}$, high: 6 to 10 fish $\mathrm{m}^{-2}$ fish density) rather than expressing a linear relationship, we also used MannWhitney's nonparametric $U$-test to evaluate differences between the 2 blocks.

\section{RESULTS}

Total phytoplankton biovolume correlated positively with fish density, increasing by 2 orders of magnitude from $0-3$ fish $\mathrm{m}^{-2}$ to $6-10$ fish $\mathrm{m}^{-2}$ (Fig. 1A). Equally, average phytoplankton GALD correlated positively, as relatively large-sized phytoplankton (Cryptophyceae) dominated at high fish densities, whereas smaller phytoplankton (various species of Bacillariophyceae and Chlorophyceae) dominated at low fish densities. Average cladoceran size correlated negatively with fish density (Fig. 1B) and average GALD of phytoplankton was negatively related to average cladoceran 

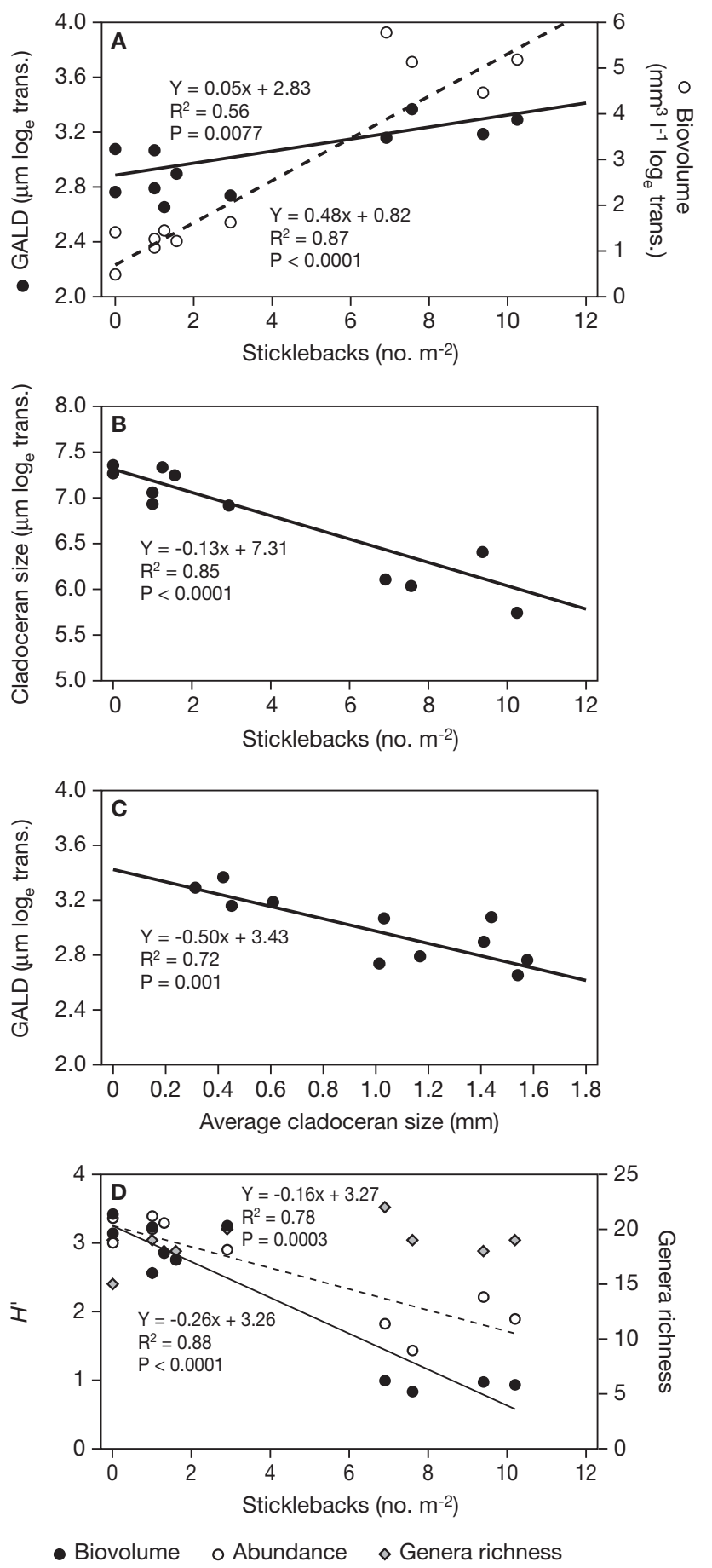

Fig. 1. Phytoplankton, Gasterosteus aculeatus and cladocerans. (A) Greatest axial linear dimension (GALD) (full regression line) and biovolume of phytoplankton (broken regression line) versus stickleback densities in the enclosures. (B) Average cladoceran size versus stickleback densities in the enclosures. (C) Average phytoplankton GALD versus average cladoceran size. (For A-C, dependent variables are $\log _{\mathrm{e}}-$ transformed.) (D) Genera richness and phytoplankton diversity $\left(H^{\prime}\right)$ based on biovolume (full regression line) and abundance (broken regression line) versus stickleback densities in the enclosures size (Fig. 1C). Phytoplankton diversity (Shannon index), based on both biovolume and abundance, was negatively related to fish density, whereas genera richness showed no clear relationship with fish density (Fig. 1D).

The phytoplankton community consisted of many different taxa (especially Bacillariophyceae and Chlorophyceae) at low fish densities, whereas Cryptomonas reflexa, Cryptomonas sp. and Gonium pectorale dominated above 3 to 6 sticklebacks m ${ }^{-2}$ (Fig. 2). Hence, the biovolume of Cryptophyceae and Chlorophyceae differed between the 2 blocks $(U=0, \mathrm{p}<$ $0.05)$, both correlating positively $\left(\mathrm{R}^{2}=0.86, \mathrm{p}<0.05\right.$ and $\mathrm{R}^{2}=0.96, \mathrm{p}<0.05$, respectively) to fish density. Biovolume of 3 other phytoplankton groups also differed between blocks, as Cyanophyceae $(U=2, \mathrm{p}<$ $0.05)$ and Prochlorothrix $(U=1, \mathrm{p}<0.05)$ increased with fish density, whereas Euglenophyceae $(U=2, \mathrm{p}<$ $0.05)$ decreased. Biovolume of Bacillariophyceae ( $U=$ $8, \mathrm{~ns})$, Dinophyceae ( $U=6, \mathrm{~ns})$ and unidentified flagellates $(U=8, \mathrm{~ns})$ showed no difference between blocks.

\section{DISCUSSION}

Our experiment showed a clear effect of sticklebacks on phytoplankton community, abundance and size structure in slightly brackish water. In accordance with investigations from freshwater lakes (e.g. Andersson et al. 1978, Søndergaard et al. 1997) increased fish

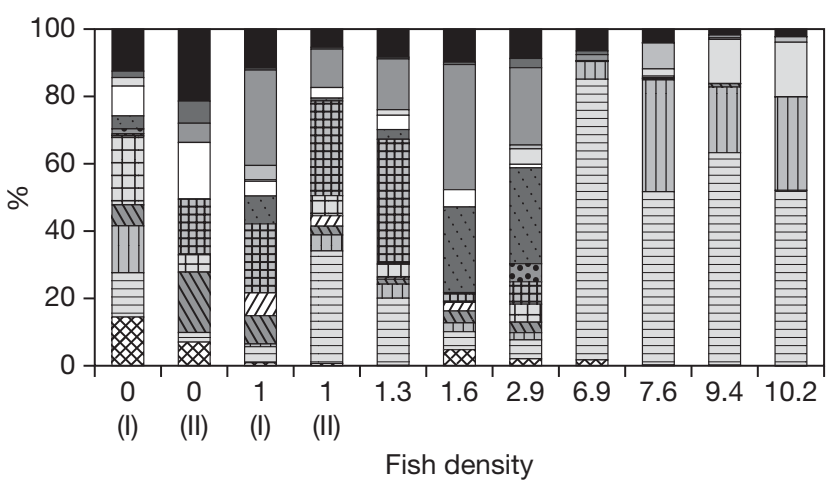

Oscillatoria limnetica
Cryptomonas sp.
III Cryptomonas reflexa
III Nitzschia sp.
WII Chaetoceros sp.
Navicula sp.
Amphora sp.
$\because$ Fragilaria sp.

Euglena spp. $\square$ Chlamydomonas spp.

$\square$ Gonium pectorale

$\square$ Pandorina morum $\square$ Sphaerocystis schroeterii - Scenedesmus opoliensis/ protuberens

Others

Fig. 2. Relative contribution (\%) of major phytoplankton taxa at different average stickleback densities. Only species contributing more than $5 \%$ of the total biovolume at any sampling date are depicted, the rest are categorised as 'Others'. Note 2 enclosures with 0 and 1 stickleback $\mathrm{m}^{-2}$ (I and II) 
density (here $>3$ to 6 sticklebacks $\mathrm{m}^{-2}$ ) led to increased biovolume of phytoplankton. The observed disappearance of large-bodied zooplankton (Daphnia) above 3 to 6 fish $\mathrm{m}^{-2}$ (Jakobsen et al. 2003) likely reduced zooplankton grazing pressure and allowed phytoplankton biovolume to increase.

Phytoplankton size (expressed as GALD) correlated negatively with average cladoceran size. This contrasts with several studies in freshwater lakes that indicate a positive relationship between phytoplankton mean size and cladoceran biomass and mean size (e.g. Burns 1968, Bergquist et al. 1985, Cottingham 1999), which is explained by a shift towards large grazing-resistant species at high grazing pressure. Yet, in enclosure experiments conducted in shallow freshwater lakes, small, fast-growing algae were found to predominate at high grazing pressure (Schriver et al. 1995, Jeppesen et al. 2002). A high growth rate can be an advantage at high grazing pressure, as fast growth enables the algal population to replace algae lost by grazing.

In our experiment higher fish densities resulted in lower phytoplankton diversity. The combination of low grazing pressure and excess nitrogen and phosphorus facilitated the dominance of a few small, fast-growing species, as also seen in an enclosure experiment in Lake Flakensee, Germany (Weithoff et al. 2000). However, the presence of Daphnia may counteract this effect (Flöder \& Sommer 1999), leaving, as in our experiment, phytoplankton diversity at a high level at fish densities below 4 to $6 \mathrm{~m}^{-2}$. That changes in topdown control affect phytoplankton diversity was equally found in a hypertrophic pond in Hungary, where an increase in phytoplankton diversity occurred after a fish kill incident (Borics et al. 2000). However, others have found an increase in diversity of primary producers following reduced grazing pressure in both aquatic and terrestrial ecosystems (e.g. Schmitz 2003). In contrast to the Shannon diversity, genera richness of phytoplankton was not affected by fish density in our experiment. In shallow lakes, however, enhanced grazing leading to enhanced water clarity may facilitate growth, temporarily or permanently, of species attached to substrates (sediment, plant surfaces or, as in our experiment, enclosure walls). Accordingly, the contribution of such benthic forms (e.g. Nitzschia, Navicula, Amphora) to the biomass was relatively high at low fish density (Fig. 2).

The phytoplankton community structure changed from a diverse assembly, as described above, to dominance by Cryptomonas spp. at fish densities above 3 to $6 \mathrm{~m}^{-2}$. This flagellate is often numerous in slightly brackish areas, such as the Bothnian Bay (Alasaarela 1979). Cryptomonas is generally highly nutritious for zooplankton (Schindler 1971), but in our study their size exceeded the upper food size of the dominant rotifers
(Keratella sp. and Brachionus sp., Jakobsen et al. 2003). The colony forming Gonium pectorale and Pandorina morum also responded positively to higher fish densities.

A high grazing pressure by Daphnia on small or readily edible algal taxa has often been shown to result in dominance of less edible, particular gelatinous, spiny or colonial forms (Gulati et al. 1982). In freshwater and slightly brackish lakes with high nutrient levels, grazing resistant algae are sometimes represented by large, colonial cyanobacteria (Cyanophyceae) (Elser \& Goldman 1991, Moss 1994). However, in our experiment Sphaerocystis schroteii was the only grazing-resistant alga that became abundant in enclosures with high grazing pressure and its dominance was recorded on only one sampling date in the beginning of August. The lack of dominance by large cyanobacteria cannot be explained by absence from the species pool, since Oscillatoria limnetica and Spirulina major individuals were occasionally observed. More likely, these species could not escape the intense grazing pressure by Daphnia sp. It has been suggested that as long as the initial density of large cyanobacteria is low and Daphnia abundance high, Daphnia is able to prevent cyanobacteria blooms (Gulati et al. 2001).

In brackish lakes and lagoons, the abundance of sticklebacks is commonly high, not least in eutrophic lakes (Pont et al. 1991, Jeppesen et al. 1994). The substantial changes in phytoplankton biovolume, composition and diversity around the interval of 3 to 6 sticklebacks $\mathrm{m}^{-2}$ recorded in our study provide experimental evidence for the empirically based conclusion of a strong cascading top-down control of planktivorous fish on phytoplankton in eutrophic brackish lakes (Jeppesen et al. 1994, 1997b). However, the results also show that in slightly brackish lakes phytoplankton can, despite high nutrient levels, be grazed down to low concentrations if the fish population declines below a certain density; in our study below 3 to 6 sticklebacks $\mathrm{m}^{-2}$.

Acknowledgements. We wish to thank L. Skov Hansen, L. Nørgaard and K. Thomsen for conducting nutrient analyses and the rest of the staff of the National Environmental Research Institute (NERI), Silkeborg, for technical assistance. We are grateful to A. M. Poulsen for editorial assistance.

\section{LITERATURE CITED}

Alasaarela E (1979) Phytoplankton and environmental conditions in central and coastal areas of the Bothnian Bay. Ann Bot Fenn 16:241-274

Andersson G, Berggren H, Cronberg G, Gelin C (1978) Effects of planktivorous fish and water chemistry in eutrophic lakes. Hydrobiologia 59:9-15

Bergquist AM, Carpenter SR, Latino JC (1985) Shifts in phytoplankton size structure and community composition during grazing by contrasting zooplankton assemblages. Limnol Oceanogr 30:1037-1045

Borics G, Grigorszky I, Szabo S, Padisak J (2000) Phytoplank- 
ton associations in a small hypertrophic fishpond in east Hungary during a change from bottom-up to top-down control. Hydrobiologia 424:79-90

Burns C (1968) The relationship between body size of filterfeeding Cladocera and the maximum size of particle ingested. Limnol Oceanogr 13:675-678

Carpenter SR, Kitchell JF, Hodgson JR, Cochran PA and 6 others (1987) Regulation of lake primary productivity by food web structure. Ecology 68:1863-1876

Cottingham KL (1999) Nutrients and zooplankton as multiple stressors of phytoplankton communities: evidence from size structure. Limnol Oceanogr 44:810-827

Elser JJ, Goldman CR (1991) Zooplankton effects on phytoplankton in lakes of contrasting trophic status. Limnol Oceanogr 36:64-90

Flöder S, Sommer U (1999) Diversity in planktonic communities: an experimental test of the intermediate disturbance hypothesis. Limnol Oceanogr 44:1114-1119

Gulati RD, Bronkhorst M, Van Donk E (2001) Feeding in Daphnia galeata on Oscillatoria limnetica and on detritus derived from it. J Plankton Res 23:705-718

Gulati RD, Siewertsen K, Postema G (1982) The zooplankton: its structure, food and feeding and role in the ecosystem of Lake Vechten. Hydrobiologia 95:127-163

Jakobsen TS, Hansen PB, Jeppesen E, Grønkjær P, Søndergaard M (2003) Impact of three-spined stickleback (Gasterosteus aculeatus) on zooplankton and chlorophyll $a$ in shallow, brackish lakes. Mar Ecol Prog Ser 262:277-284

Jensen JP, Søndergaard M, Jeppesen E, Bjerring Olsen R, Landkildehus F, Lauridsen TL, Sortkjær L, Poulsen AM (2000) Søer 1999: NOVA 2003. Danmarks Miljøundersøgelser, Silkeborg (in Danish)

Jeppesen E, Søndergaard M, Kanstrup E, Pedersen B and 5 others (1994) Does the impact of nutrients on the biological structure and function of brackish and freshwater lakes differ? Hydrobiologia 275/276:15-30

Jeppesen E, Jensen JP, Søndergaard M, Lauridsen T, Pedersen LJ, Jensen L (1997a) Top-down control in freshwater lakes: the role of nutrient state, submerged macrophytes and water depth. Hydrobiologia 342/343:151-164

Jeppesen E, Søndergaard M, Jensen JP, Kanstrup E, Pedersen B (1997b) Macrophytes and turbidity in brackish lakes with special emphasis on the role of top-down control. In:

Editorial responsibility: Otto Kinne (Editor),

Oldendorf/Luhe, Germany
Jeppesen E, Søndergaard Ma, Søndergaard Mo, Christoffersen K (eds) The structuring role of submerged macrophytes in lakes. Springer-Verlag, New York, p 369-377

Jeppesen, E, Søndergaard Ma, Søndergaard Mo, Christoffersen K, Jürgens K, Theil-Nielsen J, Schlüter L (2002) Cascading trophic interactions in the littoral zone: an enclosure experiment in shallow Lake Stigsholm, Denmark. Arch Hydrobiol 153:533-555

Kitchell JF, Carpenter SR (1993) Cascading trophic interactions. In: Carpenter SR, Kitchell JF (eds) The trophic cascade in lakes. Cambridge University Press, New York, p 230

Lampert W, Fleckner W, Rai H, Taylor BE (1986) Phytoplankton control by grazing zooplankton: a study on the spring clear-water phase. Limnol Oceanogr 31:478-490

Moss B (1994) Brackish and freshwater shallow lakes-different systems or variations on the same theme? Hydrobiologia 275/276:1-14

Olrik K (1991) Planteplankton metoder — prøvetagning, bearbejdning og rapportering ved undersøgelser af planteplankton i søer og marine områder. [Phytoplankton methods-sampling, processing and reporting at phytoplankton investigations in lakes and marine environments]. Miljøministeriet, Miljøstyrelsen, Copenhagen

Pont D, Crivelli AJ, Guillot F (1991) The impact of threespined sticklebacks on the zooplankton of a previously fish-free pool. Freshw Biol 26:149-163

Schindler JE (1971) Food quality and zooplankton nutrition. J Anim Ecol 40(3):589-595

Schmitz OJ (2003) Top predator control of plant biodiversity and productivity in an old-field ecosystem. Ecol Lett 6: 156-163

Schriver P, Bøgestrand J, Jeppesen E, Søndergaard M (1995) Impact of submerged macrophytes on fish-zooplanktonphytoplankton interactions: large-scale enclosure experiments in a shallow eutrophic lake. Freshw Biol 33:255-270

Søndergaard M, Jeppesen E, Berg S (1997) Pike (Esox lucius L.) stockings as a biomanipulation tool. 2. Effects on lower trophic levels in Lake Lyng, Denmark. Hydrobiologia 342/343:319-325

Weithoff G, Lorke A, Walz N (2000) Effects of water-column mixing on bacteria, phytoplankton, and rotifers under different levels of herbivory in a shallow eutrophic lake. Oecologia 125:91-100

Submitted: February 18, 2004; Accepted: July 6, 2004

Proofs received from author(s): September 14, 2004 